\title{
Effects of solar UV and visible irradiance on photo- synthesis and vertical migration of Oscillatoria sp. (Cyanobacteria) in an Antarctic microbial mat
}

\author{
Tracie-Lynn Nadeau ${ }^{1, *}$, Clive Howard-Williams ${ }^{2}$, Richard W. Castenholz ${ }^{1, * *}$ \\ ${ }^{1}$ Department of Biology, University of Oregon, Eugene, Oregon 97403 , USA \\ ${ }^{2}$ National Institute of Water and Atmospheric Research, PO Box 8602, Christchurch, New Zealand
}

\begin{abstract}
The migratory patterns of an Oscillatoria sp. in a hypersaline microbial mat on Antarctica's McMurdo Ice Shelf, $78^{\circ} \mathrm{S}, 166^{\circ} \mathrm{E}$, were examined under the natural solar irradiance of austral summer. Upward and downward migration was monitored in response to different intensities of full solar irradiance and of selected wavelengths achieved using a series of filter and screening treatments. $\left[{ }^{14} \mathrm{C}\right]$ photoincorporation rates, using freshly collected cell material, were also measured under different intensities and spectral regions of solar irradiance, as well as at several temperatures of incubation. Our objectives were two-fold: (1) to determine whether this cyanobacterium displays a pattern of migration, photosynthesis, and photoinhibition in response to solar UV and visible irradiance similar to that displayed by motile cyanobacteria in hypersaline ponds of middle latitudes $\left(-28^{\circ} \mathrm{N}\right)$, and (2) to examine the impact of temperature on these activities. Oscillatoria sp. migrated completely to the surface under low visible irradiance $\left(<8 \mathrm{~W} \mathrm{~m}^{-4}\right)$, green light, and complete darkness; none or these trearments included UV-B or more than $0.26 \mathrm{~W} \mathrm{~m}^{-2} \mathrm{UV}-\mathrm{A}$. Red light, which included $\sim 0.5 \mathrm{~W} \mathrm{~m}^{-2} \mathrm{UV}-\mathrm{A}$, pro-

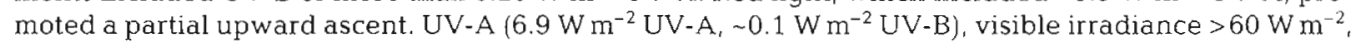
and blue light, which included $0.94 \mathrm{~W} \mathrm{~m} \mathrm{~m}^{-2} \mathrm{UV}-\mathrm{A}$, caused complete downward migration. Photosynthetic saturation occurred at low visible light levels $\left(-26 \mathrm{~W} \mathrm{~m}^{-2}\right)$, and both photo- and UV-inhibition was apparent. Photosynthetic rates increased in the order $2,<10,<15$ and $<20^{\circ} \mathrm{C}$, and there was no apparent effect of temperature on the magnitude of UV inhibition on photosynthesis. Overall trends in photosynthesis and migration patterns of Oscillatoria sp. parallel those described for benthic cyanobacteria of middle latitudes, though the Antarctic species appears to have a lower response threshold to visible light and UV. These results are consistent with the hypothesis that UV radiation is functioning as a primary cue for avoidance of damaging solar radiation in the Oscillatoria sp. population, and suggests that UV is involved in the migratory behavior of motile cyanobacteria in microbial mats worldwide.
\end{abstract}

KEY WORDS: Cyanobacterial mats · Vertical migration · Photosynthesis · Oscillatoria sp. · UV · Solar irradiance - Antarctica

\section{INTRODUCTION}

Contemporary microbial mats dominated by cyanobacteria exist in habitats usually labeled 'extreme', such as hot springs, desert soils, hypersaline waters, and polar lakes and ponds. Outside of these environments cyanobacterial mats are, at best, ephemeral.

\footnotetext{
- Present address: U.S. Geological Survery, Water Resources Division, 430 National Center, Reston, Virginia 20192, USA

- Corresponding author.

E-mail: rcasten@darkwing.uoregon.edu
}

Extreme habitats exclude efficient grazing fauna (e.g. Fenchel 1998) and thus resemble shallow marine ecosystems of the Proterozoic Eon in which stromatolitic cyanobacterial mats were widespread, prior to the evolution of metazoans capable of grazing mats (Farmer 1992). Extant mats are compact and often laminated, with cyanobacteria typically forming the uppermost layer, which is usually less than $1 \mathrm{~mm}$ thick. Photosynthesis, aerobic and anaerobic respiration, sulfatesulfur reduction and other biological processes in these mats are tightly linked due to the mats' compact nature, resulting in steep concentration gradients of 
various chemical species (Revsbech et al. 1983, Cohen \& Rosenberg 1989, Jørgensen et al. 1992). Steep gradients in irradiance and spectral quality also occur, caused by both absorption and scattering of incident radiation (Jørgensen \& Des Marais 1988, Kühl et al. 1994). These spatial gradients often change dramatically on both a diurnal and seasonal basis, exposing organisms which remain at a fixed vertical position to changing chemical and physical conditions. Many of these changes are potentially harmful, as is the case for strong solar irradiance which can cause irreversible photodamage.

UV radiation, a highly reactive component of the solar radiation flux, is known to have a broad range of biologically deleterious effects. For phototrophic organisms, vulnerable because of their dependence on photosynthetically active radiation, these effects include inhibition of photosynthesis and growth, mutagenesis, and acute physiological stress that may ultimately lead to cell death. Phototrophs have 4 lines of defense against UV exposure: avoidance, screening, quenching, and repair (Garcia-Pichel \& Castenholz 1994, Vincent \& Quesada 1994, Wynn-Williams 1994, Castenholz \& Garcia-Pichel in press). In temperate latitudes, many mat-forming filamentous cyanobacteria exhibit vertical migratory behavior, an avoidance mechanism triggered by diurnal changes in the intensity of solar irradiance (Castenholz 1968, Pentecost 1984, Richardson \& Castenholz 1987, Garcia-Pichel et al. 1994, Bebout \& Garcia-Pichel 1995). This behavior may also enable organisms to optimize light intensity, allowing maximum photosynthetic rate without inhibition (Garcia-Pichel et al. 1994), thereby improving fitness and competitive ability.

Recently, Kruschel \& Castenholz (1998) quantified effects of different components of the natural solar irradiance spectrum on migratory behavior. They examined the effects of varying the solar environment, both UV and visible irradiance, on the vertical movements of 2 filamentous cyanobacteria, Oscillatoria cf. laetevirens and Spirulina cf. subsalsa, which are major components of mats in many hypersaline ponds near Guerrero Negro, Baja California Sur, Mexico $\left(28^{\circ} \mathrm{N}\right)$. Upward migration of these organisms occurred under low visible $\left(20\right.$ to $\left.90 \mathrm{~W} \mathrm{~m}^{-2}\right)$, green $(-250$ $\left.\mathrm{W} \mathrm{m}^{-2}\right)$ and red $\left(-470 \mathrm{~W} \mathrm{~m}^{-2}\right)$ light, and complete darkness. Intensities of UV-A above $\sim 1.5$ to $2.0 \mathrm{~W} \mathrm{~m}^{-2}$ and of broad visible light above $\sim 100 \mathrm{~W} \mathrm{~m}^{-2}$ prevented upward migration, and intensities of UV-B as low as $0.1 \mathrm{~W} \mathrm{~m}^{-2}$ may have slowed it. Downward migration in Oscillatoria cf. laetevirens was promoted by high visible light $\left(>400 \mathrm{~W} \mathrm{~m}^{-2}\right.$ ) and high levels of

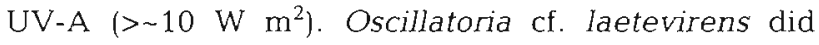
not, however, retreat from UV-B intensities as high as $0.7 \mathrm{~W} \mathrm{~m}^{-2}$. Kruschel \& Castenholz (1998) suggested that UV-B, even at these low light intensities, may have inhibited motility of the trichomes on the mat surface. They further found that UV radiation, as low as $0.05 \mathrm{~W} \mathrm{~m}^{-2}$ in the case of UV-B, inhibited shortterm photosynthesis of both organisms. Häder (1984) previously demonstrated that UV-B intensities as low as $200 \mu \mathrm{W} \mathrm{m}^{-2}(2 \mathrm{~h} \leq 300 \mathrm{~nm})$ dramatically impaired motility and photosensory responses in some cyanobacteria. Kruschel \& Castenholz (1998) concluded that UV radiation serves as an effective cue in the migratory behavior of Oscillatoria cf. laetevirens and Spirulina cf. subsalsa.

Oscillatorian cyanobacteria dominate the benthic mats that occur in the abundant meltwater ponds on the ablation moraine of Antarctica's McMurdo Ice Shelf (Vincent 1988, Wynn-Williams 1990, Vincent et al. 1993a). In these ponds, water temperatures during the short open season of 2 to 3 mo seldom rise above $8^{\circ} \mathrm{C}$ (Hawes et al. 1999), and many deeper ponds never lose their central ice core. In the latter, the water temperature does not rise above $4^{\circ} \mathrm{C}$ (Vincent 1988). Since the development of the Antarctic ozone hole, there has been much research to discern the implications of the associated increase in transmission of UV radiation, particularly on planktonic communities (see Weiler \& Penhale 1994). Because benthic cyanobacteria play a major role in the lakes, ponds, and streams of the Antarctic, and since many of these communities inhabit shallow waters where they are exposed to full solar radiation in summer months, their capacity to respond to changing UV fluxes is an issue of concern (Vincent \& Quesada 1994).

Despite the dominance of benthic filamentous cyanobacteria, there have been no empirical studies examining the possible role of vertical migratory behavior as a mechanism to minimize the adverse effects of UV radiation in Antarctic microbial mats. Migratory behavior of a motile oscillatorian has previously been observed in a hypersaline pond in the Bratina Island region of the McMurdo Ice Shelf (Vincent et al. 1993a). In the present study, we sought to elucidate patterns of migration, photosynthesis, and photo- and UV-inhibition in response to both ambient and modified natural solar irradiance in this organism, and to compare these patterns to those of the motile cyanobacteria of Guerrero Negro (Kruschel \& Castenholz 1998). A corollary objective was to examine the impact of temperature on these activities. Results provide insight into the direct effects of solar UV radiation on the migratory strategy of this oscillatorian in an Antarctic benthic mat, as well as our larger objective to ascertain whether UV radiation is a migratory cue common to motile cyanobacteria which are prevalent in microbial systems of extreme habitats worldwide. 


\section{MATERIALS AND METHODS}

Research site. Salt Pand is one of thousands of meltwater ponds occurring on the ablation zone of Antarctica's McMurdo Ice Shelf, $\sim 78^{\circ} \mathrm{S}, 166^{\circ} \mathrm{E}$. Although migratory behavior by cyanobacteria was observed in benthic mats in other meltwater ponds, it was most pronounced in Salt Pond, the site chosen for this study.
Salt Pond is a shallow, hypersaline pond covering an area of $-220 \mathrm{~m}^{2}$ (Fig. 1A) and surrounded by a salt deposit enriched in mirabilite $\left(\mathrm{Na}_{2} \mathrm{SO}_{4} \cdot 10 \mathrm{H}_{2} \mathrm{O}\right.$; HowardWilliams et al. 1989). In January 1998, when this study was conducted, it had a salinity of $\sim 53 \%$ (American Optical Refractometer). Unlike the thick, laminated, gelatinous benthic mats commonly associated with other hypersaline waters, this thin benthic mat con-
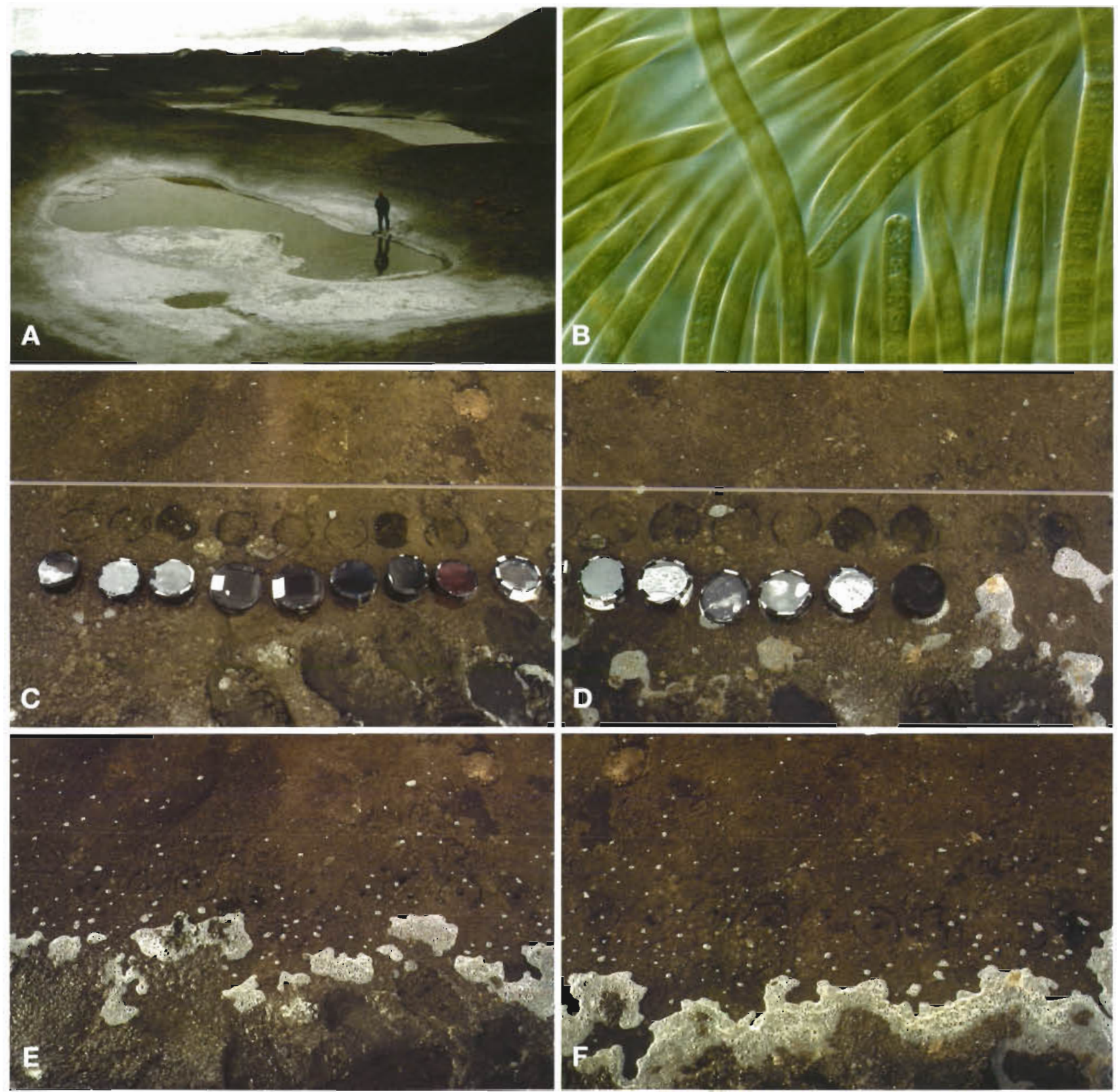

Fig. 1. (A) Salt Pond, McMurdo Ice Shelf (Brack Pond and Bratina Island in the background). (B) Oscillatoria sp. 'K' trichomes $(-7 \mu \mathrm{m}$ in diameter). (C,D) Upward migration of Oscillatoria sp. ' $K$ ' in Salt Pond, after $3 \mathrm{~h}$ of treatment, from left to right: $D, D+3$, $\mathrm{D}+6, \mathrm{UV}-\mathrm{A}, \mathrm{UV}-\mathrm{A} / \mathrm{B}$, blue, green, red, $\mathrm{P}, \mathrm{P}+3, \mathrm{P}+6, \mathrm{~S}, \mathrm{~S}+3, \mathrm{~S}+6$, dark (see Table 1 and 'Materials and methods' for description). $(E, F)$ In response to the removal of filter treatments from $(C, D)$ and exposure to full solar irradiance for several hours, Oscillatoria $\mathrm{sp}$. ' $\mathrm{K}$ ' migrated back below the surface of the mat (note ring and central coring marks) 
tains much inorganic sediment composed of silt and sand. A large, motile oscillatorian, 6 to $7 \mu \mathrm{m}$ in diameter, dominates the mat (Fig. 1B). Previously referred to as Oscillatoria cf. priestleyi (e.g. Vincent et al. 1993a,b), it is morphologically classified as morphotype K in Broady \& Kibblewhite's (1991) characterization of Antarctic oscillatoriales. Phormidium (=Leptolyngbya) sp., Amphipleura sp., a smaller naviculoid diatom and a unicellular eukaryote were other photosynthetic members of the mat. These, however, were rare in comparison to the dominant cyanobacterium, herein referred to as Oscillatoria sp. ' $K$ '. Sequence analysis of $16 \mathrm{~S}$ rDNA indicates that Oscillatoria sp. ' $\mathrm{K}$ ' is the same organism that was dominant in the pond in January 1990 (Nadeau \& Castenholz unpubl. data), when the migratory behavior was first observed. Growth studies performed in the laboratory on isolates of this organism indicate that it is psychrotolerant (Castenholz \& Schneider 1993, Nadeau \& Castenholz unpubl. data), capable of growth near the freezing point of water yet having a temperature optimum $>15^{\circ} \mathrm{C}$. During the period of this study, the temperature of Salt Pond, in the shallow region where experiments were conducted, ranged from 1.6 to $10.7^{\circ} \mathrm{C}$ and averaged $\sim 6.0^{\circ} \mathrm{C}$. Over $24 \mathrm{~h}$ on a sunny day, the temperature commonly ranged from $\sim 2$ to $\sim 8^{\circ} \mathrm{C}$.

Irradiance measurements and radiation alteration. Throughout each of the experiments, incident radiation was repeatedly measured with an International Light Research Radiometer (IL 1700) for 3 wavebands: visible+IR (400 to $>1000 \mathrm{~nm}$ ), UV-A (320 to $400 \mathrm{~nm}$ ), and UV-B (280 to $320 \mathrm{~nm}$ ). Reported values were measured for the surface of the water, which was a few $\mathrm{cm}$ above the mat. Incident solar radiation was altered using broad band transmission screens with sharp UV cut-offs, as well as zero to 6 neutral density screens. The combinations and intensities (in $\mathrm{W} \mathrm{m}^{-2}$ ) are noted in figure legends. The styrene filter (K-lite UVF CS, Plaskolite Inc, Columbus, OH) blocks most UV radiation $(50 \% \mathrm{~T}$ at $395 \mathrm{~nm}, 5 \% \mathrm{~T}$ at $385 \mathrm{~nm})$, whereas the polyester filter (Cadillac Piastics, Baltimore, MD) mostly blocks the UV-B region $(46 \% \mathrm{~T}$ at $330 \mathrm{~nm},<1 \% \mathrm{~T}$ at $310 \mathrm{~nm})$. Control cellulose diacetate filters transmit both UV-A and UV-B $(\sim 5 \% \mathrm{~T}$ at $287 \mathrm{~nm}, 50 \% \mathrm{~T}$ at $295 \mathrm{~nm}$ ). All 3 filters transmit $\sim 90 \%$ of visible light. Transmittance spectra for UV-blocking and colored filter materials are shown in Fig. 2.

Data shown in Fig. 6 were collected continuously, at 10 min intervals, with a Campbell CR10 data logger, using sensors (Macam Photometrics Ltd, Livingston, Scotland, UK) mounted $3 \mathrm{~m}$ above the surface of the McMurdo Ice Shelf. Calibration was by comparison with output from an UVM spectrometer maintained at the National Institute of Water and Atmospheric Research, Lauder, New Zealand.

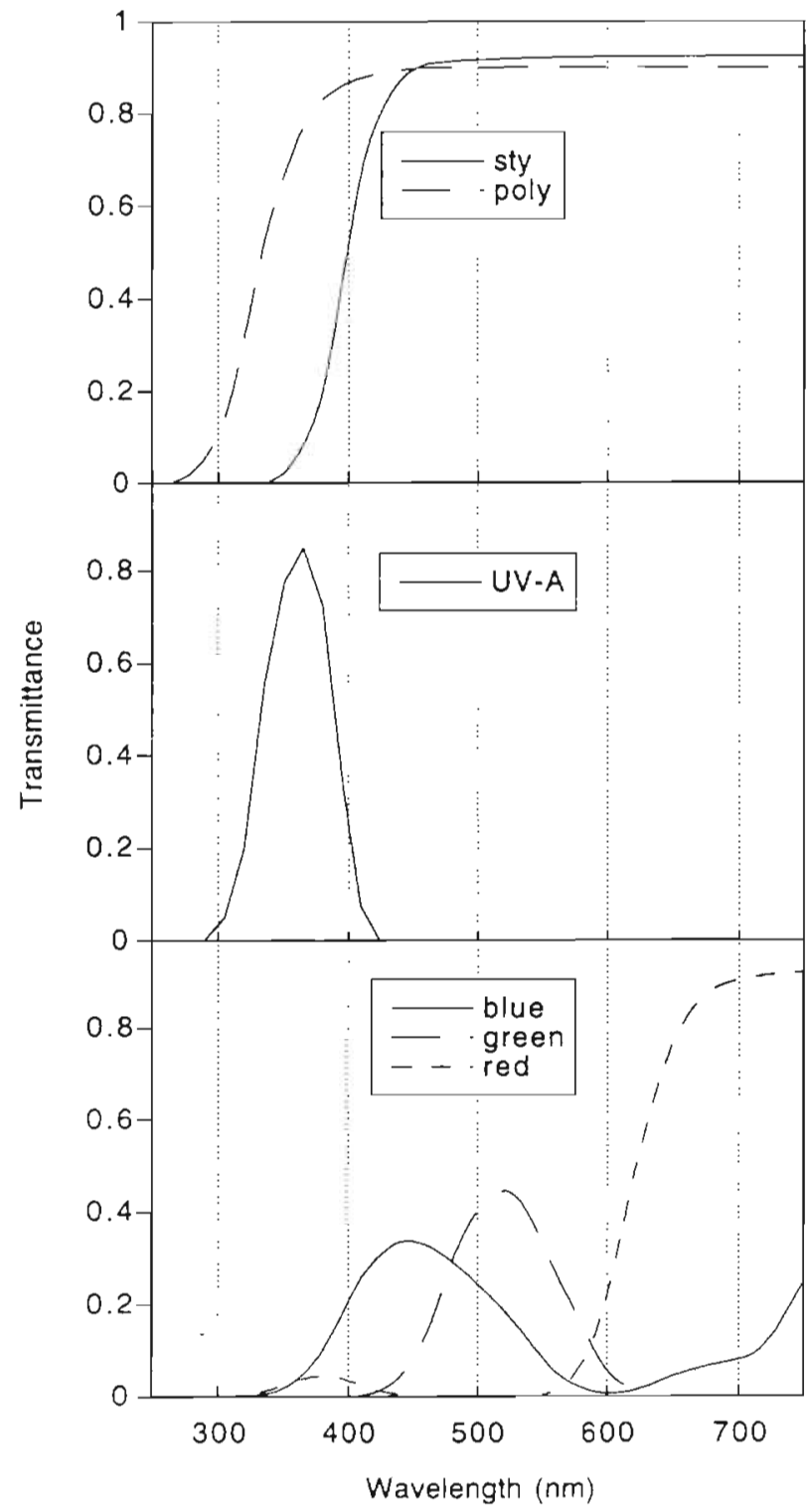

Fig. 2. Transmittance spectra for filter materials

Migration experiments. Filtering devices were constructed by mounting round pieces of filter, with or without neutral density screens, onto thin plastic cylinders ( $8 \mathrm{~cm}$ in diameter, $3 \mathrm{~cm}$ high) which are opaque except for 2 bottom-side openings cut for water exchange. The cylinders were pushed part way into the soft mat material for the 3 to $6 \mathrm{~h}$ duration of each experiment, exposing the encircled mat to whatever radiation was transmitted by the filter. No prepatory treatment was necessary prior to upward migration experiments, in that the motile population of trichomes was below the surface of the mat during the $24 \mathrm{~h}$ daylight of austral summer. However, prior to downward migration experiments, the mat was covered with a dark filter for several hours, 
which allowed ascent of the motile trichomes to the mat surface. The composition of this mat, with its high silt and sand content, made it impossible to use the minicore technique of Garcia-Pichel et al. (1994) to quantify the vertical position of the migrating cyanobacterial band. Instead, the migration response was graded on a scale of 0 to 4 based on visual observation. Core samples, $1 \mathrm{~cm}$ in diameter and $\sim 5 \mathrm{~cm}$ in thickness, were taken for chlorophyll a (chl a) measurements. These were mechanically disrupted, extracted overnight in $95 \%$ methanol, and quantified spectrophotometrically using the equation of Lenz \& Zeitschel (1968).

Irradiance, UV, and temperature effects on photosynthesis. Photoincorporation of $\left[{ }^{14} \mathrm{C}\right] \mathrm{NaHCO}_{3}$ was used as a measure of photosynthesis in 3 different types of experiments: (1) quantification of photo- and UVinhibition on photosynthetic capacity under 3 different ranges of the solar spectrum (visible alone, visible+UV$A$, visible $+U V-A / B$ ) and 3 different intensities (using neutral density screens), (2) characterization of the time course of photosynthetic uptake under the same 3 regions of the solar spectrum after $30,60,90$, and $120 \mathrm{~min}$ of incubation, and (3) determination of the effects of these solar spectral ranges as a function of incubation temperature. Prior to these experiments, an opaque cover was placed over a portion of the mat for $>7 \mathrm{~h}$ during the low sun period of $24 \mathrm{~h}$ daylight which allowed the Uscilatoria sp. ' $\mathrm{K}$ popuiation iu unigraie iu ilue snai surface. The population of freely dissociating trichomes was harvested, using a wide-bore syringe, and resuspended uniformly in native pond water which had been filtered 3 to 5 times through Whatman ${ }^{\mathrm{TM}} \mathrm{GF} / \mathrm{C}$ filters to remove phytoplankton. Cell suspensions were used within 1 to $3 \mathrm{~h}$ of collection. Aliquots $(7.5 \mathrm{ml})$ of the diluted suspension were distributed to $2 \mathrm{oz}$ Whirl-Pak ${ }^{\mathrm{TM}}$ bags (NASCO), followed by addition of $\left[{ }^{14} \mathrm{C}\right]$ sodium bicarbonate to achieve a final activity of $2.96 \mathrm{kBq} \mathrm{ml}^{-1}$ $(0.08 \mu \mathrm{Ci})$. Each light treatment included duplicate samples, with dark samples used as controls.

Microscopic examination of fixed subsamples from cell suspensions showed the presence of a small photosynthetic flagellate, a probable cryptomonad, $\sim 4 \mu \mathrm{m}$ in diameter. Cell counts combined with steriometric formulae, in which trichomes were considered cylinders and flagellates were considered spheres, were used to calculate biovolume. By these calculations Oscillatoria sp. ' $\mathrm{K}$ ' constituted $98.9 \%$ of the biovolume; thus, results were attributed to this species.

Type 1 incubations were for $1.5 \mathrm{~h}$ and those for the time series (Type 2) were as indicated in the figure legend. Both Type 1 and Type 2 incubations were performed in trays in a shallow pond at ambient temperature, which remained constant, $\pm 1.5^{\circ} \mathrm{C}$, within each experiment. Replicate experiments were carried out on different days; temperature of incubation among the experiments varied from about 5 to $11^{\circ} \mathrm{C}$. Type 3 experiments were incubated on the surface of waterfilled insulated coolers which were maintained at temperatures of 2 to $3,10,15$, and $20^{\circ} \mathrm{C}$ by frequent additions of hot water. Samples were acclimated for $2 \mathrm{~h}$ at the incubation temperature prior to $2 \mathrm{~h}$ photoincorporation incubations.

Incubations were stopped by the addition of formalin to $\sim 5 \%$ final concentration. Samples were stored in the dark, for 1 to $3 \mathrm{wk}$, until processed. This involved filtration onto Gelman GN-6 membrane filters, acidification with $2 \%(\mathrm{v} / \mathrm{v})$ concentrated $\mathrm{HCl}$, and rinsing with double-distilled water. Filters were transferred to scintillation vials to which $7.5 \mathrm{ml}$ of OptiPhase 'HighSafe' 3 (Wallac) scintillation cocktail was added, and stored overnight at $4{ }^{\circ} \mathrm{C}$. $\left[{ }^{14} \mathrm{C}\right]$ photoincorporation was quantified by liquid scintillation counting (Wallac LKB 1217 Rackbeta). Resulting disintegrations per minute (DPM) data were normalized to chl a content, determined spectrophotometrically from methanol extracted samples (Lenz \& Zeitschel 1968).

Statistical analyses. Analysis of variance (ANOVA), analysis of covariance (ANCOVA), and regression analyses (Sokal \& Rohlf 1995) were made using SuperANOVA. (Abacus Concepts 1989). Two-factor ANOVA models for each photoincorporation experiment type, using $\left[{ }^{14} \mathrm{C}\right]$ uptake data, were categorized as follows: (1) groups of

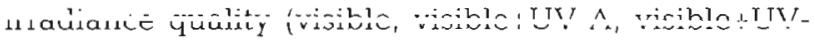
$\mathrm{A} / \mathrm{B})$ and intensity $(2.2,14,38,85 \%)$, (2) groups of radiation intensity/quality (85\%visible+UV-A/B, $85 \%$ visible, $14 \%$ visible) and incubation time $(30,60,90,120 \mathrm{~min})$, and (3) groups of radiation intensity/quality ( $85 \%$ visible+UV-A/B, $85 \%$ visible+UV-A, $85 \%$ visible or $85 \%$ visible+UV-A/B, $38 \%$ visible+UV-A/B, $9 \%$ visible+UV-A/B) and incubation temperature $\left(2.2,10,15,20^{\circ} \mathrm{C}\right)$. Mean percent UV inhibition and $95 \%$ interval estimates were calculated using the Bliss theorem (Hubert 1992), as previously described (Miller et al. 1998). Other analyses are described below in the 'Results' section.

\section{RESULTS}

\section{Migration}

Migration of Oscillatoria sp. ' $\mathrm{K}$ ' was vividly evidenced by changes in coloration of the mat surface in response to various treatments (Fig. $1 \mathrm{C}$ to $\mathrm{F}$ ). The mat was grayish-yellow during the $24 \mathrm{~h}$ daylight of the austral summer, but changed to dark green when the motile component migrated upward. Migration was apparent after 2 to $3 \mathrm{~h}$ under filters which elicited the most rapid response. Table 1 presents the results of migration experiments, as well as incident and treatment irradiance values. 
Table 1. Results of upward and downward migration experiments and key to irradiance transmitted through filter/screening combinations used as treatments. Scoring on a scale of 0 to 4 , with $0=$ no migration and $4=$ maximum migration; thus a score of 4 for upward migration means the trichomes came completely to the surface of the mat, but in downward migration it means the trichomes completely left the mat surface. Upward migration irradiance values represent the range in measurements from 3 experiments. During duplicate downward migration experiments, full incident radiation was essentially the same. All experiments were $-4 \mathrm{~h}$ in duration. D: diacetate, transmits UV-A/B. P: polyester, blocks UV-B. S: styrene, blocks nearly all UV. ND: no data. Numbers in treatment column denote number of neutral density screens used

\begin{tabular}{|c|c|c|c|c|c|c|c|c|}
\hline \multirow[t]{2}{*}{ Treatment } & \multirow{2}{*}{$\begin{array}{l}\text { Upward } \\
\text { migration } \\
\text { Score }\end{array}$} & \multicolumn{3}{|c|}{$\begin{array}{l}\text { Irradiance transmitted } \\
\text { through filters }\left(\mathrm{W} \mathrm{m}^{-2}\right)\end{array}$} & \multirow{2}{*}{$\begin{array}{l}\text { Downward } \\
\text { migration } \\
\text { Score }\end{array}$} & \multicolumn{3}{|c|}{$\begin{array}{l}\text { Irradiance transmitted } \\
\text { through filters }\left(\mathrm{W} \mathrm{m}^{-2}\right)\end{array}$} \\
\hline & & VIS & UV-A & UV-B & & VIS & UV-A & UV-B \\
\hline Full irradiance & & $230-360$ & $13.4-14.4$ & $0.78-0.81$ & & 459 & 18.6 & 1.1 \\
\hline $\mathrm{D}$ & 0 & $203-318$ & $11.5-12.4$ & $0.63-0.72$ & 4 & 405 & 16 & 0.89 \\
\hline$D+3$ & 0 & $34.2-53.4$ & $1.7-1.8$ & $0.09-0.1$ & $3-4$ & 68.2 & 2.7 & 0.14 \\
\hline$D+4$ & 1 & $12-18.8$ & $0.62-0.67$ & 0 & 3 & 24 & 1.0 & 0 \\
\hline$D+6$ & $3-4$ & $4.8-7.6$ & $0.2-0.25$ & 0 & 0 & 9.6 & 0.34 & 0 \\
\hline $\mathrm{P}$ & 0 & $193-302$ & $9.4-10$ & $0.25-0.27$ & 4 & 385 & 13 & 0.36 \\
\hline$P+3$ & 0 & $29.3-45.7$ & $1.5-1.6$ & 0 & 4 & 58.5 & 2.1 & 0 \\
\hline$P+6$ & $3-4$ & $4.4-7.8$ & $0.24-0.26$ & 0 & ND & 10 & 0.33 & 0 \\
\hline S & 0 & $140-220$ & $1.3-1.4$ & 0 & 4 & 279 & 1.8 & 0 \\
\hline$S+3$ & $0-1$ & $30-47$ & $0.2-0.22$ & 0 & $1-2$ & 60.1 & 0.28 & 0 \\
\hline$S+4$ & 1 & $129-20$ & 0.1 & 0 & 1 & 25.9 & 0.14 & 0 \\
\hline$S+6$ & 4 & $4.2-6.5$ & 0 & 0 & 0 & 8.4 & 0.04 & 0 \\
\hline UV-A & 0 & $13.0-20$ & $4.9-5.3$ & 0 & 4 & 26 & 6.9 & 0.1 \\
\hline Blue & 0 & $87.6-137$ & $0.68-0.7$ & 0 & 4 & 175 & 0.94 & 0 \\
\hline Green & 4 & $55.6-87$ & 0 & 0 & 0 & 111 & 0 & 0 \\
\hline Red & $2-3$ & $108-169$ & 0.5 & 0 & $0-2$ & 216 & 0.66 & 0 \\
\hline Dark & $3-4$ & & & & 0 & & & \\
\hline
\end{tabular}

To insure that negative results were due to prevention of upward vertical movement, and not distributional heterogeneity in the Oscillatoria sp. ' $\mathrm{K}$ ' population, chl a was used as a correlative to estimate biomass of Oscillatoria sp. ' $\mathrm{K}$ ' under each treatment in the upward migration experiments. To this end, core samples were taken from under all filters at the end of each experiment. The average concentration ( $\mu \mathrm{g} \mathrm{chl} \mathrm{a} \mathrm{cm}^{-2} \pm \mathrm{SE}$ ) for the upward migration experiments shown in Table 1 were 36.3 (2.54), $20.0(1.20)$, and 26.3 (2.25). Relative homogeneity of the population within each experiment is demonstrated by the low variance in chlorophyll measurements.

The Oscillatoria sp. ' $\mathrm{K}$ ' population migrated completely to the surface under low visible irradiance $(<8 \mathrm{~W}$ $\mathrm{m}^{-2}$ ), green light, and complete darkness (Table 1). None of these treatments included UV-B or more than $0.26 \mathrm{~W} \mathrm{~m}^{-2}$ UV-A. Red light, which included $\sim 0.5 \mathrm{~W}$ $\mathrm{m}^{-2} \mathrm{UV}-\mathrm{A}$, also allowed a considerable upward ascent, but to a lesser extent. Green light elicited the most pronounced response. Noticeable upward migration occurred at a higher visible irradiance when most of the UV was blocked $\left(\mathrm{S}+3 ; \sim 0.22 \mathrm{~W} \mathrm{~m}^{-2} \mathrm{UV}-\mathrm{A}, 0 \mathrm{~W} \mathrm{~m} \mathrm{~m}^{-2}\right.$ UV-B) in contrast to treatments with the same neutral density screening which transmitted UV-A/B (D+3;

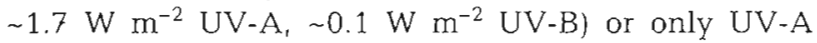
$\left(\mathrm{P}+3 ; \sim 1.5 \mathrm{~W} \mathrm{~m} \mathrm{~m}^{-2} \mathrm{UV}-\mathrm{A}\right)$. Even partial upward ascent did not occur under any treatments which included a measurable UV-B component.
The sections of mat used for downward migration experiments were uniformly dark green due to the forced upward migration of Oscillatoria sp. ' $\mathrm{K}$ ' prior to the start of these experiments, indicating relative homogeneity of trichome distribution. Filters which elicited the most pronounced responses resulted in the disappearance of Oscillatoria sp. ' $\mathrm{K}$ ' from the surface within 2 to $3 \mathrm{~h}$ of treatment. Oscillatoria sp. ' $\mathrm{K}$ ' displayed a maximal downward migratory response to UV-A $\left(6.9 \mathrm{~W} \mathrm{~m}^{-2} \mathrm{UV}-\mathrm{A}_{1} \sim 0.1 \mathrm{~W} \mathrm{~m}^{-2} \mathrm{UV}-\mathrm{B}\right)$, high visible irradiance ( $>60 \mathrm{~W} \mathrm{~m}^{-2}$ ) and blue light, which included $0.94 \mathrm{~W} \mathrm{~m}^{-2} \mathrm{UV}$-A (Table 1). Responses to high visible light are difficult to interpret, in that these treatments also included a UV-A component. However, several filter combinations which transmitted low visible light and some UV-A (e.g. D+6, S+4, S+6; Table 1) did not cause extensive downward migration, yet any treatment which transmitted UV-B did. Trichomes remained on the surface of the mat under treatments which had allowed upward migration in the experiments described earlier.

\section{Photosynthetic carbon assimilation}

Type 1

This was a 2-way factorial design in which spectral quality and irradiance level were varied. There were 3 
light quality treatments (visible+UV-A/B, visible+UV$\mathrm{A}$, and visible alone) and 4 irradiance levels $(85,38,14$, and $2.2 \%$ ). Results from experiments performed under incident solar irradiance encountered during both a clear and an overcast day, $460 \mathrm{~W} \mathrm{~m}^{-2}$ and $186 \mathrm{~W} \mathrm{~m}^{-2}$ respectively, are shown (Fig. $3 \mathrm{~A}, \mathrm{~B}$ ). In both cases, 2-way ANOVA resulted in highly significant effects $(\mathrm{p} \leq$ 0.0005 ) of both spectral quality and irradiance level on photosynthetic carbon assimilation. However, there was also a significant interaction term between these factors ( $p<0.01$ ), indicating that cells respond differently to UV at different irradiance levels.

In the experiment conducted at the higher absolute irradiance level (Fig. 3A), post hoc tests of 2-way ANOVA indicated no significant differences between visible+UV-A/B and visible+UV-A, though both differ significantly $(p=0.0001)$ from the treatment in which only visible light was available. In the absence of UV, photosynthetic saturation was reached at $60 \mathrm{~W} \mathrm{~m}^{-2}$. An increase to $365 \mathrm{~W} \mathrm{~m}^{-2}$ resulted in photoinhibition. Inhibition was already apparent at the $14 \%$ irradiance level in the visible+UV-A $\left(\sim 54.8 \mathrm{~W} \mathrm{~m}^{-2}\right.$ vis, $\sim 1.8 \mathrm{~W} \mathrm{~m}^{-2}$

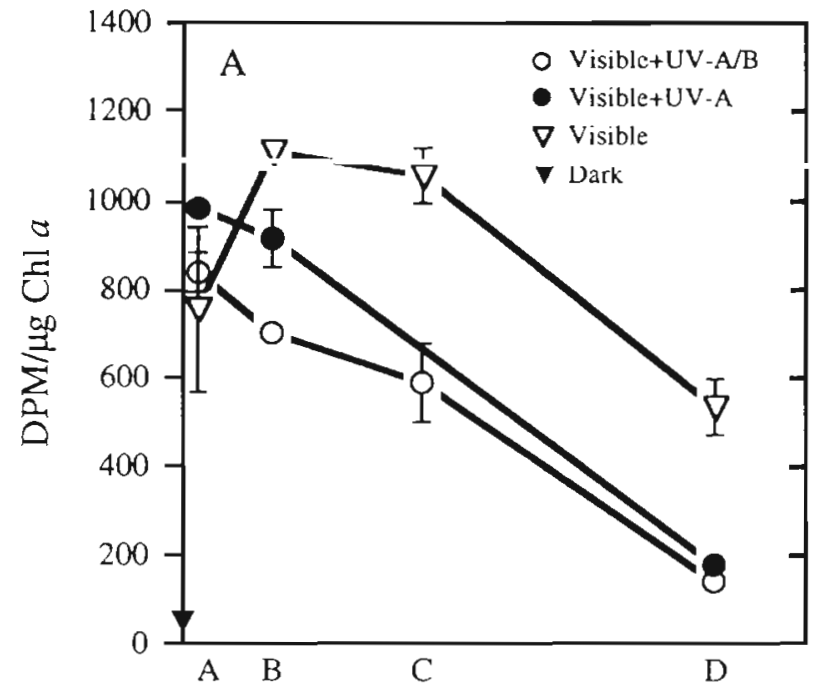

UV-A) and visible+UV-A/B $\left(-63.9 \mathrm{~W} \mathrm{~m}^{-2}\right.$ vis, $\sim 2.3 \mathrm{~W}$ $\left.\mathrm{m}^{-2} \mathrm{UV}-\mathrm{A}, \sim 0.14 \mathrm{~W} \mathrm{~m}^{-2} \mathrm{UV}-\mathrm{B}\right)$ treatments.

In the experiment conducted during overcast conditions (Fig. 3B) the photosynthetic rate saturated between $26 \mathrm{~W} \mathrm{~m}^{-2}$ and $70 \mathrm{~W} \mathrm{~m}^{-2}$ under visible light alone. Post hoc tests of 2-way ANOVA indicated no significant difference between these 2 treatments, however, so saturation was likely reached near $26 \mathrm{~W} \mathrm{~m}^{-2}$. There was only slight inhibition at $158 \mathrm{~W} \mathrm{~m}^{-2}$, the $85 \%$ irradiance level. Maximal photosynthesis was reached at $14 \%$ irradiance under both visible+UV-A $\left(\sim 23.7 \mathrm{~W} \mathrm{~m}^{-2}\right.$ vis, $\left.\sim 1.1 \mathrm{~W} \mathrm{~m} \mathrm{~m}^{-2} \mathrm{UV}-\mathrm{A}\right)$ and visible+UV-A/B $(\sim 27.6 \mathrm{~W}$ $\mathrm{m}^{-2}$ vis, $\sim 1.5 \mathrm{~W} \mathrm{~m}^{-2}$ UV-A, $\sim 0.01 \mathrm{~W} \mathrm{~m}^{-2}$ UV-B), while further increases in both treatments caused inhibition.

To further investigate the interaction term in these experiments, 2-factor ANOVA was repeated using data from the 2 lowest light intensities, 2.2 and $14 \%$, including all 3 UV treatments. For the experiment performed at the higher absolute light level (Fig. 3A), this analysis showed no significant effects $(p>0.13)$ of either radiation quality or intensity. Furthermore, the significance level of the interaction term was greatly

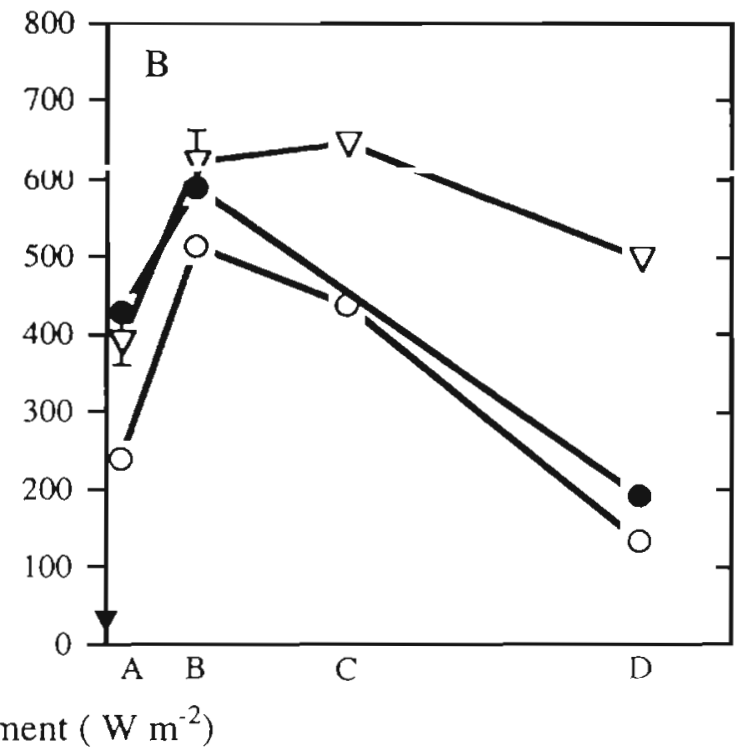

A

\begin{tabular}{|lcrrr|}
\hline Treatment & \% incident radiation & Vis & UV-A & UV-B \\
\hline A & 2.2 & 10 & 0.4 & 0.02 \\
B & 14 & 60 & 2.2 & 0.2 \\
C & 38 & 163 & 6.1 & 0.4 \\
D & 85 & 365 & 13.7 & 0.9 \\
& 100 & 430 & 16.1 & 1.1 \\
\hline
\end{tabular}

\section{B}

\begin{tabular}{|lcrrr|}
\hline Treatment & \% incident radiation & Vis & UV-A & UV-B \\
\hline A & 2.2 & 4 & 0.2 & 0.01 \\
B & 14 & 26 & 1.5 & 0.1 \\
C & 38 & 71 & 4.0 & 0.3 \\
D & 85 & 158 & 9.0 & 0.6 \\
& 100 & 186 & 10.6 & 0.7 \\
\hline
\end{tabular}

Fig. 3. Chl a normalized photosynthetic $\left[{ }^{14} \mathrm{Cl}\right.$-bicarbonate incorporation of Oscillatoria sp. ' $\mathrm{K}$ ' over $1.5 \mathrm{~h}$. Cells were assayed at the irradiances indicated under diacetate (visible+UV-A/B), polyester (visible+UV-A), and styrene (visible) filters. Weather conditions were $(\mathrm{A})$ clear and sunny, incubation temperature $-5.6^{\circ} \mathrm{C}$, and $(\mathrm{B})$ overcast, incubation temperature $\sim 5.2^{\circ} \mathrm{C}$. There are no data for the $38 \%$ visible+UV-A treatment. Error bars represent SE 
reduced $(p>0.05)$. However, in the lower absolute light level experiment (Fig. 3B) both radiation quality and intensity still had significant effects $(p=0.001)$, and the interaction term was not significant. In the latter experiment, the cells were under subsaturating light conditions at the 2 lower light treatments.

\section{Type 2}

These experiments evaluated the time course of inhibitory effects under 3 different solar environments (Fig. 4). A 2-way ANOVA resulted in a highly significant effect ( $p=0.0001$ ) of both solar environment and incubation time, though the interaction of the 2 terms was also significant $(p=0.008)$. The lowest irradiance treatment, $64 \mathrm{~W} \mathrm{~m}^{-2}$ of visible light alone, gave the highest photoincorporation rates. For this treatment, $\left[{ }^{14} \mathrm{C}\right]$ uptake fits a linear model $\left(\mathrm{r}^{2}=0.885, \mathrm{p}=0.001\right)$ over the $120 \mathrm{~min}$ incubation period. Photoinhibition occurred by $60 \mathrm{~min}$ of incubation at the highest intensity $\left(85 \% ; 391 \mathrm{~W} \mathrm{~m}^{-2}\right)$ of visible irradiance. Application of $85 \%$ visible+UV-A/B $\left(17.2 \mathrm{~W} \mathrm{~m}^{-2} \mathrm{UV}-\mathrm{A}, \sim 0.97 \mathrm{~W}\right.$ $\mathrm{m}^{-2} \mathrm{UV}-\mathrm{B}$ ) caused inhibition after only $30 \mathrm{~min}$ of incubation. Relative to the highest uptake rates achieved at $14 \%$ of visible light alone, uptake under the $85 \%$ visible $+\mathrm{UV}-\mathrm{A} / \mathrm{B}$ treatment was only $10 \%$ greater than that of the dark control throughout the $2 \mathrm{~h}$ incubation.

To test the effect of UV inclusion at the $85 \%$ intensity level, a 1-factor ANCOVA model was used in which uptake was treated as the dependent variable with

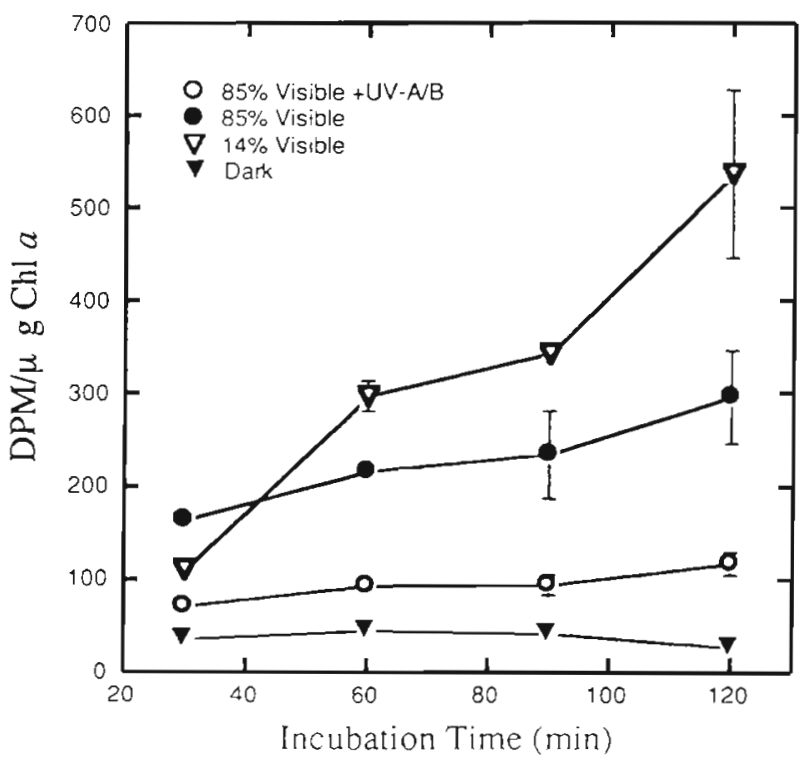

Fig. 4. Time course of chl a normalized photosynthetic $\left[{ }^{14} \mathrm{C}\right]-$ bicarbonate incorporation of Oscillatoria sp. ' $\mathrm{K}$ ' over $2 \mathrm{~h}$ at $\sim 8^{\circ} \mathrm{C}$. Mean $100 \%$ irradiance values are $402 \mathrm{~W} \mathrm{~m}^{-2}$ visible, $17.8 \mathrm{~W} \mathrm{~m}^{-2} \mathrm{UV}-\mathrm{A}, 1.1 \mathrm{~W} \mathrm{~m}^{-2} \mathrm{UV}-\mathrm{B}$. Error bars represent SE
UV as the factor and incubation time as the regressor. The hypothesis of homogeneity of slopes could not be rejected $(p=0.06)$, so the interaction involving the covariate was eliminated from the model. The resulting $F$-value was highly significant $\left(F_{[1,13]}=63.07, \mathrm{p}=0.0001\right)$, indicating that the means of the $85 \%$ visible $\pm \mathrm{UV}$ treatments vary significantly. Because there is no interaction of light quality with time, the absolute difference between these 2 light treatments stayed the same over the incubation period. The mean UV inhibition of carbon uptake was estimated at $58 \% \pm 12 \%$.
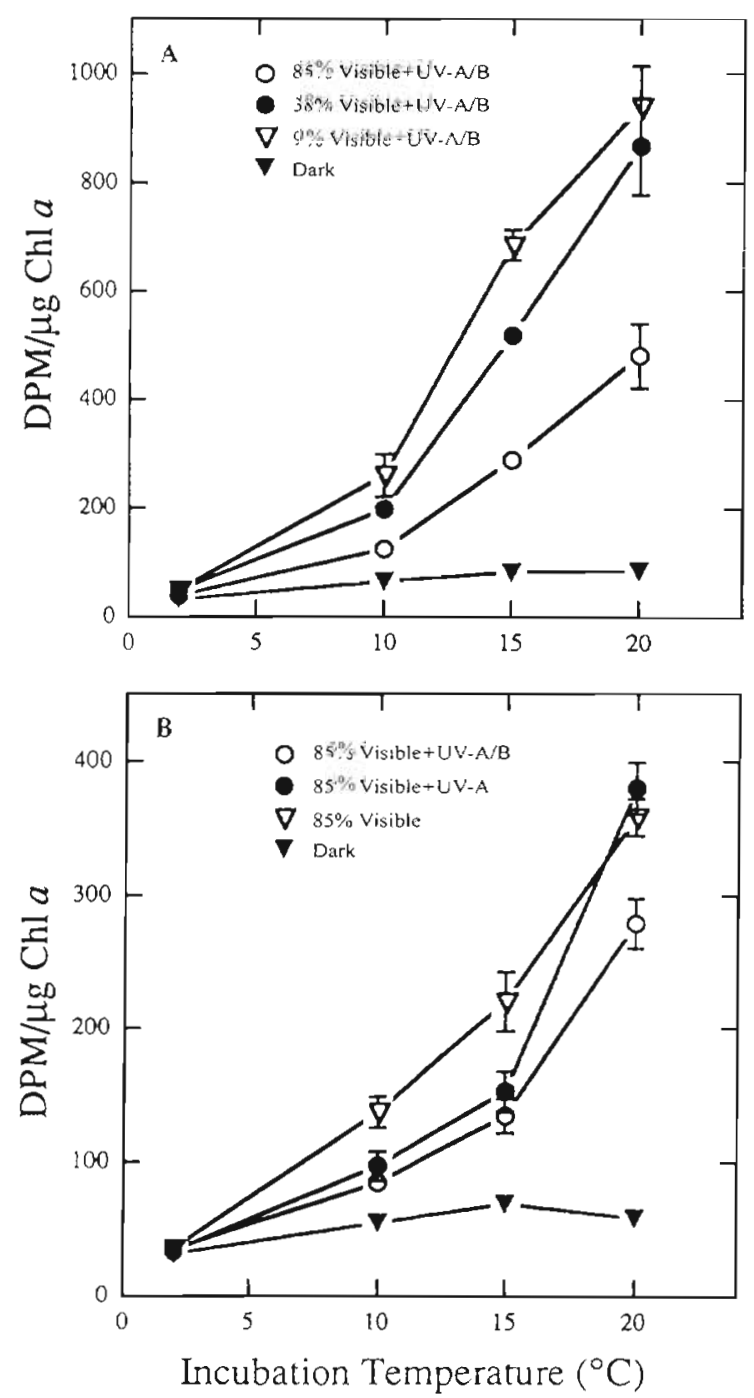

Fig. 5. Effect of visible and UV irradiance on photosynthetic carbon uptake of Oscillatoria sp. ' $\mathrm{K}$ ' as a function of incubation temperature. Cells were acclimated for $2 \mathrm{~h}$ at the appropriate temperatures prior to $2 \mathrm{~h}$ incubations. (A) Treatments vary in percent radiation; UV-A/B was transmitted for all treatments. Mean $100 \%$ irradiance values were $163 \mathrm{~W} \mathrm{~m}^{-2}$ visible, $9.3 \mathrm{~W} \mathrm{~m}^{-2} \mathrm{UV}$-A, $0.5 \mathrm{~W} \mathrm{~m}^{-2} \mathrm{UV}$-B. (B) Treatments vary in UV component transmitted. Mean $100 \%$ irradiance values were $300 \mathrm{~W} \mathrm{~m}^{-2}$ visible, $12.5 \mathrm{~W} \mathrm{~m}^{-2} \mathrm{UV}-\mathrm{A}, 0.63 \mathrm{~W} \mathrm{~m}^{-2} \mathrm{UV}-\mathrm{B}$. Error bars represent $\mathrm{SE}$ 
Type 3

These experiments evaluated the effects of temperature and irradiance on photosynthesis (Fig. 5). Absolute irradiance values were low during these experiments because of overcast conditions. 2-factor ANOVA resulted in highly significant effects of both irradiance and temperature $(\mathrm{p} \leq 0.0003$ both experiments), though there was a significant irradiance-byincubation temperature interaction term $(p \leq 0.01)$. At $2^{\circ} \mathrm{C}$ (Fig. 5) uptake did not differ significantly from the dark control for any of the irradiance treatments. Thus, 2 -factor ANOVA was repeated excluding these data, which resulted in a much reduced significance level ( $p \geq 0.05$ for both experiments) for the interaction term. In each experiment, photosynthetic rates increased in the order $2,<10,<15$ and $<20^{\circ} \mathrm{C}$; within any given light treatment the greatest $\left[{ }^{14} \mathrm{C}\right]$ uptake was always at $20^{\circ} \mathrm{C}$.

Varying the percent irradiance, while transmitting UV (Fig. 5A), resulted in the lowest carbon assimilation rates at the highest light treatment $\left(85 \% ; 143 \mathrm{~W} \mathrm{~m}^{-2}\right.$ vis, $\left.8 \mathrm{~W} \mathrm{~m}^{-2} \mathrm{UV}-\mathrm{A}, 0.4 \mathrm{~W} \mathrm{~m}^{-2} \mathrm{UV}-\mathrm{B}\right)$. The highest carbon assimilation rates occurred under the $9 \%$ visible+UV-A/B treatment $\left(14.6 \mathrm{~W} \mathrm{~m}^{-2}\right.$ vis, $0.5 \mathrm{~W} \mathrm{~m}^{-2} \mathrm{UV}$ -

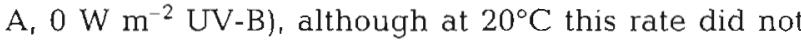
differ significantly from that of the $38 \%$ visible+UV-

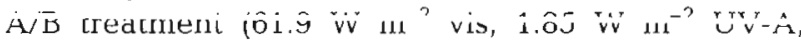
$0.09 \mathrm{~W} \mathrm{~m}^{-2}$ UV-B).

Results of a similar experiment, in which the intensity of visible irradiance remained constant while the UV conditions varied (Fig. 5B), showed lowest photosynthetic rates in the visible+UV-A/B treatment $(255 \mathrm{~W}$ $\mathrm{m}^{-2}$ vis, $\left.10.7 \mathrm{~W} \mathrm{~m}^{-2} \mathrm{UV}-\mathrm{A}, 0.5 \mathrm{~W} \mathrm{~m}^{-2} \mathrm{UV}-\mathrm{B}\right)$. Visible+ UV-A resulted in equally low rates at 10 and $15^{\circ} \mathrm{C}$, but at $20^{\circ} \mathrm{C}$ did not significantly differ from the visible only treatment. A 1-factor ANCOVA model was used to test the effect of temperature on the magnitude of UV inhibition in this experiment. In this model, uptake was treated as the dependent variable with UV as the factor and incubation temperature as the regressor. The homogeneity of slopes hypothesis could not be rejected $(p=0.3)$, indicating no interaction of light quality with temperature. Thus, there was no apparent effect of temperature on the magnitude (percent) of UV inhibition on photosynthesis.

\section{DISCUSSION}

\section{Photosynthetic activity}

The solar irradiance values presented in Fig. 3A are among the highest recorded during the month of January 1998. UV-inhibition was detected as low as
$-60 \mathrm{~W} \mathrm{~m}^{-2}$ visible irradiance plus $-2.5 \mathrm{~W} \mathrm{~m}^{-2} \mathrm{UV}-\mathrm{A} / \mathrm{B}$ (Fig. 3A), but with visible light only Oscillatoria sp. ' $\mathrm{K}$ ' showed no inhibition at this intensity. The rate of convergence towards the dark uptake values was significantly higher when UV was included. At the highest light level, uptake rates for both UV-A and UV-A/B treatments were not much higher than the dark control, i.e. the cells were almost completely inhibited. In the Baja cyanobacteria (Kruschel \& Castenholz 1998) the inclusion of UV-A or UV-A/B radiation with high visible irradiance similarly inhibited photosynthesis almost to dark levels.

Under overcast conditions (Fig. 3B), there is evidence that cells of Oscillatoria sp. ' $\mathrm{K}$ ' were photosynthetically saturated at visible light intensity as low as $\sim 26 \mathrm{~W} \mathrm{~m}^{-2}$, and photoinhibited by $\sim 158 \mathrm{~W} \mathrm{~m}^{-2}$ of visible light alone. However, the inclusion of UV radiation was clearly detrimental to photosynthetic uptake, even at extremely low intensities $\left(\sim 0.25 \mathrm{~W} \mathrm{~m}^{-2} \mathrm{UV}-\mathrm{A}\right.$ and $\left.-0.02 \mathrm{~W} \mathrm{~m}^{-2} \mathrm{UV}-\mathrm{B}\right)$. In contrast, visible intensities above $-350 \mathrm{~W} \mathrm{~m}^{-2}$, and inclusion of $\sim 0.8 \mathrm{~W} \mathrm{~m}^{-2} \mathrm{UV}-\mathrm{A}$ plus $\sim 0.05 \mathrm{~W} \mathrm{~m}^{-2} \mathrm{UV}-\mathrm{B}$, caused inhibition in the migrating cyanobacteria (i.e. Oscillatoria cf. laetevirens) of the Baja ponds (Kruschel \& Castenholz 1998). It would appear then, on the basis of these few experiments, that the Antarctic Oscillatoria is somewhat more sensitive to visible and UV irradiance than the

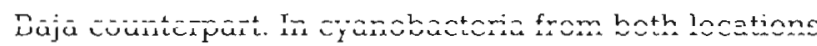
it is unknown whether exposure over a longer period would allow recovery through repair processes. In a laboratory experiment, Vincent \& Quesada (1994) showed that 5 d growth of a culture of Oscillatoria cf. priestleyi (=Oscillatoria sp. ' $\mathrm{K}$ ') was completely suppressed by $5 \mathrm{~W} \mathrm{~m}^{-2} \mathrm{UV}-\mathrm{B}$, as compared to the control which doubled at $0.44 \mathrm{~d}^{-1}$. However, this UV-B value is considerably higher than would be experienced in the Antarctic pond

The detrimental effect of UV on photosynthetic uptake began soon, if not immediately, after exposure (Fig. 4). However, at a photoinhibiting visible light level $\left(\sim 390 \mathrm{~W} \mathrm{~m}^{-2}\right)$ an increase in UV dose (i.e. time of exposure) did not alter the degree of UV inhibition. Given the high level of UV inhibition experienced by these field samples of Oscillatoria sp. ' $\mathrm{K}$ ', it obviously benefits the trichomes to remain deeper in the mat and thus avoid even moderate solar UV radiation.

At $2.2^{\circ} \mathrm{C}$ (Fig. 5A,B), a temperature which Oscillatoria sp. ' $\mathrm{K}$ ' probably experiences often during the austral summer, there was no measurable effect of irradiance because the photoincorporation rates were no greater than the dark values. There was active photosynthesis, however, at the average temperature measured in Salt Pond $\left(6.0^{\circ} \mathrm{C}\right)$ in January. Even at the highest temperature recorded in Salt Pond, $10.7^{\circ} \mathrm{C}$, it is apparent that Oscillatoria sp. ' $\mathrm{K}$ ' was existing at sub- 
optimal temperatures. These data agree with those obtained for a laboratory clone of this organism, which showed that both growth and photosynthetic rates reach an optimum at temperatures above $20^{\circ} \mathrm{C}$ (Castenholz \& Schneider 1993, Nadeau \& Castenholz unpubl. data).

Results of photosynthetic activity in Oscillatoria sp ' $\mathrm{K}$ ' differ from those of laboratory experiments performed on a cultured oscillatorian, Phormidium murrayi West \& West, isolated from an Antarctic microbial mat (Roos \& Vincent 1998). Roos \& Vincent found no significant effect of UV radiation $1.25 \mathrm{~W} \mathrm{~m}^{-2} \mathrm{UV}-\mathrm{A}$, $0.25 \mathrm{~W} \mathrm{~m}^{-2}$ UV-B and up to $500 \mu \mathrm{mol}$ photons $\mathrm{m}^{-2} \mathrm{~s}^{-1}$ visible) on short-term (1 h) photosynthesis at 5, 10, 15, and $20^{\circ} \mathrm{C}$ in cultures grown under non-UV radiation and low light conditions at $20^{\circ} \mathrm{C}$. They attribute these results to UV radiation dosage rates which were too low to elicit a detectable response. However, after $5 \mathrm{~d}$ of growth under the same visible irradiance levels and temperatures, $\pm U V$, they did find that photosynthetic carbon uptake rates $(1 \mathrm{~h})$ were reduced an average of $30 \%$ by the presence of UV radiation. In both sets of experiments, there was little evidence of photoinhibition up to $500 \mu \mathrm{mol} \mathrm{m}^{-2} \mathrm{~s}^{-1}$ of visible irradiance alone in Phormidium murrayi. Oscillatoria sp. ' $\mathrm{K}$ ' was photoinhibited at much lower irradiance levels (Fig. 5A). These differences, though, are not surprising given the migratory capabilities of Oscillatoria sp. ' $\mathrm{K}$ '. If migratory behavior is a mechanism to avoid damage from high solar and UV irradiance, having maximal photosynthetic capabilities at low light levels, due to a high light-harvesting pigment content, is a necessary counterpart which allows optimization of this physical parameter. There was no significant effect of temperature on the magnitude (percent) of UV inhibition of photosynthesis for either Phormidium murrayi or Oscillatoria sp. ' $\mathrm{K}$ ' (the latter in our experiments; Fig. 5B).

\section{Migration}

There is a broad range of incident visible wavelengths and intensities that allow or promote upward migration of Oscillatoria $\mathrm{sp}$. ' $\mathrm{K}$ ' to the mat surface (Table 1). The most pronounced upward response occurred under treatments which had neither a UV-A or UV-B component, although the population did move partially, or fully, to the surface under treatments of low visible irradiance that had some UV-A $\left(<\sim 0.6 \mathrm{~W} \mathrm{~m}^{-2}\right)$. However, removal of UV was not sufficient to promote upward migration, in that higher levels of full spectrum visible irradiance also prevented upward movement. Downward migration occurred most significantly in response to high visible $\left(>60 \mathrm{~W} \mathrm{~m}^{-2}\right)$ or UV $\left(6.9 \mathrm{~W} \mathrm{~m}^{-2} \mathrm{UV}-\mathrm{A}, \sim 0.1 \mathrm{~W} \mathrm{~m}^{-2} \mathrm{UV}-\mathrm{B}\right)$ treatments. Low visible light $\left(<\sim 10 \mathrm{~W} \mathrm{~m}^{-2}\right)$ in combination with a low intensity of UV-A $\left(<-0.34 \mathrm{~W} \mathrm{~m}^{-2}\right)$ did not force this cyanobacterium down from the mat surface.

Migration experiments were performed on migratory cyanobacteria in hypersaline ponds of Guerrero Negro (Kruschel \& Castenholz 1998) at near optimal temperatures, whereas comparable experiments on Oscillatoria sp. ' $\mathrm{K}$ ' were at suboptimal temperatures for motility in this cyanobacterium. The motility rate of the Baja Oscillatoria at 25 to $30^{\circ} \mathrm{C}$ was $\sim 1 \mu \mathrm{m} \mathrm{s} \mathrm{s}^{-1}$, while Oscillatoria sp. ' $\mathrm{K}$ ' moved at speeds of 2.4 (0.24), 0.9 (0.18), and $0.4(0.12) \mu \mathrm{m} \mathrm{s} \mathrm{s}^{-1}$ at 22,12 , and $4^{\circ} \mathrm{C}$, respectively. Distances from the top of the cyanobacterial band to the surface was $\sim 0.4$ to $0.5 \mathrm{~mm}$ in mats at both sites. Even though Oscillatoria sp. ' $\mathrm{K}$ ' would have moved somewhat more slowly at the temperatures at which migration experiments were performed $\{\sim 4$ to $8^{\circ} \mathrm{C}$ ), sufficient time was allowed for a full migratory response, making it possible to compare results.

Although we could not quantify exact vertical positions within the mat, our results corroborate the results of Kruschel \& Castenholz (1998). They found that complete upward migration did not take place if UV-A was $>\sim 2 \mathrm{~W} \mathrm{~m}^{-2}$ for Spirulina cf. subsalsa, and that no upward migration occurred for Oscillatoria cf. laetevirens if UV-A was above $1.5 \mathrm{~W} \mathrm{~m}^{-2}$. The Antarctic cyanobacterium Oscillatoria sp. ' $\mathrm{K}$ ' responded with similar sensitivity to both visible and UV radiation, but appears to have a somewhat lower threshold for eliciting upward or downward migratory behavior. For instance, Spirulina cf. subsalsa fully ascended to the surface under $22 \mathrm{~W} \mathrm{~m}^{-2}$ visible and $0.8 \mathrm{~W} \mathrm{~m}^{-2} \mathrm{UV}-\mathrm{A}$, whereas Oscillatoria sp. ' $\mathrm{K}$ ' only partially rose to the surface under $20 \mathrm{~W} \mathrm{~m}^{-2}$ visible and $0.1 \mathrm{~W} \mathrm{~m}^{-2} \mathrm{UV}-\mathrm{A}$ (Table 1). Furthermore, a treatment of $24 \mathrm{~W} \mathrm{~m}^{-2}$ visible and $1.0 \mathrm{~W} \mathrm{~m}^{-2} \mathrm{UV}$-A caused nearly total downward migration in the Antarctic cyanobacterium, whereas even $350 \mathrm{~W} \mathrm{~m}^{-2}$ of visible plus $1.4 \mathrm{~W} \mathrm{~m}^{-2} \mathrm{UV}-\mathrm{A}$ had little effect on Oscillatoria cf. laetevirens, although Spirulina cf. subsalsa was somewhat more sensitive (Kruschel \& Castenholz 1998).

Oscillatoria sp. ' $\mathrm{K}$ ' displayed a response to colored light similar to that of the Baja cyanobacteria, in which green light promoted the fastest ascent, red light promoted a slower ascent, with no ascent under blue light. This has been described in other motile cyanobacteria, as well, with the probable implication of positive phototaxis under green light which hastens the ascent (Castenholz 1982).

\section{Ecological implications}

Photosynthesis is one of the prime processes inhibited by UV (see Holm-Hansen et al. 1993). As primary productivity in Antarctic ponds is mainly that of filamentous 
cyanobacteria which dominate these microbial benthic habitats, the severity of UV stress is a factor in the composition of these mat systems. Natural levels of UV radiation drastically inhibit photosynthesis in Oscillatoria sp. ' $\mathrm{K}$ '; this inhibition begins immediately upon exposure and is constant over the range of temperatures which this microorganism experiences in its natural habitat.

Overall trends in photosynthesis and migration patterns of Oscillatoria sp. ' $\mathrm{K}$ ' parallel those described for Spirulina cf. subsalsa and Oscillatoria cf. laetevirens, which dominate soft mats of many hypersaline ponds of Guerrero Negro (Kruschel \& Castenholz 1998). The most surprising aspect of this study, in view of their disparate environments and geographic locations, is the similarity of the Antarctic cyanobacterial responses to those of the Baja organisms. Oscillatoria $\mathrm{sp}$. ' $\mathrm{K}$ ' is quite different from Oscillatoria cf. laetevirens both with respect to morphology and $16 \mathrm{~S}$ rDNA nucleotide sequences (Nadeau \& Castenholz unpubl. data). The slight differences observed in the irradiance level thresholds that are required to elicit a response in these cyanobacteria may be due to genetic differences or to the different solar environments of their respective habitats. At $78^{\circ} \mathrm{S}$ the clear sky fluence density of UV radiation and of visible irradiance is only about half that of middle latitudes. This is due to the low sun angle at high latitudes. Although the sun remains above the

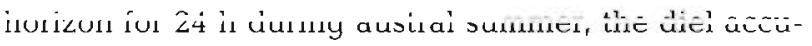
mulative dosage of UV may not be as important as the midday intensity level, which may be seriously detrimental even in the few hours of maximum intensity.

Although Antarctic microbial communities are not subjected to as severe UV intensities as occur in many lower latitudes, they may nevertheless be encountering increasing intensities to which they have not been previously adapted. In the case of natural populations of Oscillatoria sp. ' $\mathrm{K}$ ', it appears that this cyanobacterium is more sensitive to UV radiation than the Oscillatoria cf. laetevirens and Spirulina cf. subsalsa at $28^{\circ} \mathrm{N}$ in Baja California, both with regard to vertical migratory behavior and inhibition of photosynthesis. This small difference, however, may simply reflect a greater sensitivity of photosynthesis to UV radiation at low temperatures, which might also apply to the Baja cyanobacteria at suboptimal temperatures. Laboratory isolates of Oscillatoria sp. ' $\mathrm{K}$ ' showed relatively poor photosynthesis and growth at the normal, but suboptimal, temperatures of the field (Castenholz \& Schneider 1993, Nadeau \& Castenholz unpubl. data). In field experiments (Fig. 5B), this cyanobacterium showed significantly lower UV-A inhibition of photosynthesis when the temperature was raised to $20^{\circ} \mathrm{C}$, close to its temperature optimum.

In the Baja mats, migratory cyanobacteria come to the surface at dusk and remain there through dawn; they are also seen at the surface during periods of high turbidity. It is possible that the UV avoidance strategy is not used frequently, or at all, by the Baja cyanobacteria because of the usual turbidity of the hypersaline waters where they now commonly occur. Thus, it may be that these responses evolved in other, more UVexposed habitats, but have been retained in these specialized environments. Oscillatoria sp. ' $\mathrm{K}$ ', however, makes good use of its response system in Salt Pond. During the $24 \mathrm{~h}$ daylight of austral summer (Fig. 6), solar irradiance is high enough, even on overcast days or during turbid conditions, to prevent Oscillatoria sp. ' $\mathrm{K}$ ' from ascending to the surface. Results from our experiments, in which this cyanobacterium showed $>50 \%$ UV-inhibition of photosynthesis on a clear day, suggest that a surface population would probably deteriorate as a result of UV-inhibition. Oscillatoria $\mathrm{sp}$. ' $\mathrm{K}$ ' has neither UV-absorbing microsporine amino acid (MAA)-like compounds nor the extracellular sunscreen pigment scytonemin, UV defense mechanisms used by other cyanobacteria (Garcia-Pichel \& Castenholz 1993); its migratory strategy is a primary defense mechanism against UV exposure. This is also true of the migratory cyanobacteria of Baja.

Like the Baja populations, not only avoidance, but actual optimization of the photosynthetic light field may also exist in the Salt Pond population. During the lü suir poricd of austral summor bath DAD and ITY levels can drop significantly (Fig. 6), and some upward movement towards the mat surface may occur. Nonetheless, the only time that Oscillatoria sp. ' $\mathrm{K}$ ' populations are likely to be found on the mat surface would be during the transition periods of spring or fall. For

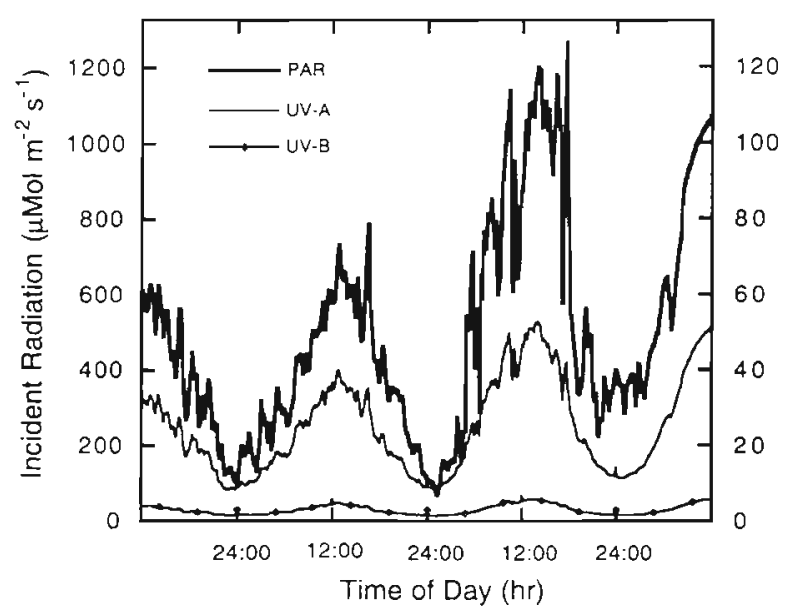

Fig. 6. PAR, UV-A, and UV-B at the study site for the $72 \mathrm{~h}$ period from 12:00 h on 8 January to $12: 00 \mathrm{~h}$ on 10 January 1998, illustrating irradiance values for both an (A) overcast and a (B) clear, sunny day. Note order of magnitude difference in scale between PAR and UV values. In general, $\sim 1 \mathrm{~W}$ $\mathrm{m}^{-2} \mathrm{PAR}=2.15 \mu \mathrm{mol} \mathrm{m} \mathrm{m}^{-2} \mathrm{~s}^{-1}$ 
instance, during the 1997 summer/winter transition the shallow area of 2 McMurdo Ice Shelf ponds, generally the zone of maximal biomass, froze between late February and early Marchi into late March, however, the surface incident irradiance was still at a daily average of 40 to $100 \mu \mathrm{mol} \mathrm{m}^{-2} \mathrm{~s}^{-1}$ ( 19 to $46 \mathrm{~W} \mathrm{~m}^{-2} \mathrm{PAR}$ ), suggesting 12 to $30 \mu \mathrm{mol} \mathrm{m} \mathrm{m}^{-2} \mathrm{~s}^{-1}$ at mat depth (Hawes et al. 1999). Furthermore, liquid water temperatures in a brackish pond stayed over $\sim 2^{\circ} \mathrm{C}$ until late February (Hawes et al. 1999). Under such an environmental scenario, it is conceivable that the motile population of Salt Pond migrates to the mat surface to optimize photosynthesis, until that point when temperatures become physiologically prohibitive.

It is probable that Oscillatoria sp. ' $\mathrm{K}$ ' occurs in habitats which are thermally suboptimal because it is neither grazed by herbivores, which are excluded from this extreme habitat, nor outcompeted by other photosynthetic organisms. While migratory capabilities contribute to its success, the monospecific dominance of Oscillatoria sp. ' $\mathrm{K}$ ' in Salt Pond may be partially explained by the hypersalinity of this habitat, which appears to exclude the other common species growing in the fresher water ponds of the region. Though isolates of Oscillatoria sp. ' $\mathrm{K}$ ' grow well in freshwater medium (Nadeau \& Castenholz unpubl. data), this morphotype is usually found only in high conductivity waters of the McMurdo Ice Shelf (Broady \& Kibblewhite 1991, Nadeau \& Castenholz unpubl. data).

It is tempting to predict that migratory filamentous cyanobacteria have a common ancestor that possessed a UV/high light avoidance response, perhaps during an earlier period in the Earth's history (Proterozoic) when UV-B flux was considerably higher than at present. The alternative view is less attractive, since the similarity in response sensitivity shared by Oscillatoria sp. 'K', Oscillatoria cf. laetevirens, and Spirulina cf. subsalsa would suggest that 3 or more cyanobacteria independently evolved almost identical, complex response systems to UV and high visible irradiance.

In conclusion, our results are consistent with the hypothesis that UV radiation is functioning as a primary cue for avoidance of damaging solar radiation in the oscillatorian population of Salt Pond. This study, considered together with research conducted in middle (Kruschel \& Castenholz 1998) and lower (Bebout \& Garcia-Pichel 1995) latitudes, strongly suggests that $\mathrm{UV}$ is involved in the migratory behavior of motile cyanobacteria in soft mats worldwide. Further work is necessary, however, to fully understand the interactions between high solar irradiance, UV radiation, and temperature as stress factors which impact the physiological status of benthic Antarctic cyanobacteria, and therefore their migratory behavior and the ecology of the aquatic ecosystems which they dominate.
Acknowledgements. Many thanks to the National Institute of Water and Atmospheric Research, New Zealand, for making this work possible, especially Ian Hawes and Rob Smith. We also thank Antarctica New Zealand for logistical support, Antonio Quesada and Eduardo Fernandez-Valiente for assistance in the field, Scott Miller for insightful discussions, and 2 anonymous reviewers for comments which improved the manuscript. Air transport was provided by the U.S. Navy and the Royal New Zealand Air Force. This work received support from the New Zealand Foundation for Research Science and Technology Contract No. C01601. T.-L.N. was partially supported by a National Science Foundation research training grant (no. DBI-9413223) to the Department of Biology at the University of Oregon.

\section{LITERATURE CITED}

Abacus Concepts (1989) SuperANOVA. Abacus Concepts Inc, Berkeley

Bebout BM, Garcia-Pichel F (1995) UV B-induced vertical migrations of cyanobacteria in a microbial mat. Appl Environ Microbiol 61:4215-4222

Broady PA, Kibblewhite AL (1991) Morphological characterization of Oscillatoriales (cyanobacteria) from Ross Island and southern Victoria Land, Antarctica. Antarct Sci 3:35-45

Castenholz RW (1968) The behavior of Oscillatoria terebriformis in hot springs. J Phycol 4:132-139

Castenholz RW (1982) Motility and taxes. In: Carr NG, Whitton BA (eds) The biology of cyanobacteria. Blackwell Scientific Publishers, Oxford, p 413-440

Castenholz RW, Garcia-Pichel F (in press) Cyanobacterial responses to UV-radiation. In: Whitton BA, Potts $M$ (eds) Ecology of cyanobacteria: their diversity in time and space. Kluwer Academic Publications, Dordrecht

Castenholz RW, Schneider AJ (1993) Cyanobacterial dominance at high and low temperatures: optimal conditions or precarious existence? In: Guerrero R, Pédrós-Alió C (eds) Trends in microbial ecology. Spanish Society for Microbiology, Barcelona, p 19-24

Cohen Y, Rosenberg E (eds) (1989) Microbial mats. Physiological ecology of benthic microbial communities. American Society for Microbiology, Washington, DC

Farmer $J$ (1992) Grazing and bioturbation in modern microbial mats. In: Schopf JW, Klein C (eds) The proterozoic biosphere. Cambridge University Press, New York, p 295-297

Fenchel T (1998) Formation of laminated cyanobacterial mats in the absence of benthic fauna. Aquat Microb Ecol 14: $235-240$

Garcia-Pichel F, Castenholz RW (1993) Occurrence of UVabsorbing, mycosporin-like compounds among cyanobacterial isolates and an estimate of their screening capacity. Appl Environ Microbiol 59:163-169

Garcia-Pichel F, Castenholz RW (1994) On the significance of solar ultraviolet radiation for the ecology of microbial mats. In: Stal LJ, Caumette $\mathrm{P}$ (eds) Microbial mats: structure, development and environmental significance. Springer Verlag, Heidelberg, p 77-84

Garcia-Pichel F, Mechling M, Castenholz RW (1994) Diel migrations of microorganisms within a benthic, hypersaline mat community. Appl Environ Microbiol 60: $1500-1511$

Häder DP (1984) Effects of UV-B on motility and photo-orientation in the cyanobacterium, Phormidium uncinatum. Arch Microbiol 140:34-39

Hawes I, Smith R, Howard-Williams C, Schwarz AM (1999) Environmental conditions during freezing, and response 
of microbial mats in ponds of the McMurdo Ice Shelf, Antarctica. Antarct Sci 11:198-208

Holm-Hansen O, Lubin D, Heibling EW (1993) Ultraviolet radiation and its effect on organisms in aquatic environments. In: Young AR, Björn LO, Moan J, Nultsch W (eds) Environmental UV photobiology. Plenum Press, New York, p 379-425

Howard-Williams C, Pridmore R, Downes MT, Vincent WF (1989) Microbial biomass, photosynthesis and chlorophyll a related pigments in the ponds of the McMurdo Ice Shelf, Antarctica. Antarct Sci 1:125-131

Hubert JJ (1992) Bioassay. KendalyHunt Publishing Co, Dubuque, IA

Jørgensen BB, Des Marais DJ (1988) Optical properties of benthic photosynthetic communities: fiber-optic studies of cyanobacterial mats. Limnol Oceanogr 33:99-113

Jørgensen BB, Castenholz RW, Pierson BK (1992) The microenvironment within modern microbial mats. In: Schopf JW, Klein C (eds) The Proterozoic biosphere. Cambridge University Press, Cambridge, p 271-278

Kruschel C, Castenholz RW (1998) The effect of solar UV and visible irradiance on the vertical movements of cyanobacteria in microbial mats of hypersaline waters. FEMS Microbiol Ecol 27:53-72

Kühl M, Lassen C, Jørgensen BB (1994) Optical properties of microbial mats: light measurements with fiber optic microprobes. In: Stal LJ, Caumette P (eds) Microbial mats: structure, development and environmental significance. Springer Verlag, Heidelberg, p 150-165

Lenz J, Zeitschel B (1968) Zur Bestimmung des Extinktionkoeffezienten für Chlorophyll $a$ in Methanol. Kiel Meeresforsch 24:41-50

Miller SR, Wingard CE, Castenholz RW (1998) Effects of visible light and $U V$ radiation on photosynthesis in a population of a hot spring cyanobacterium, Synechococcus sp, subjected to high-temperature stress. Appl Environ Microbiol 64:3893-3899

Pentecost A (1984) Effects of sedimentation and light intensity on mat-forming Oscillatoriaceae with particular reference to Microcoleus lyngbyaceus Gomont. J Gen Microbiol 130: 983-990

Editorial responsibility: David Karl,

Honolulu, Hawaii, USA
Revsbech NP, Jørgensen BB, Blackburn TH, Cohen Y (1983) Microelectrode studies of the photosynthesis and $\mathrm{O}_{2}, \mathrm{H}_{5} \mathrm{~S}$ and $\mathrm{pH}$ profiles of a microbial mat. Limnol Oceanogr 28:1062-1074

Richardson LL, Castenholz RW (1987) Diel vertical movements of the cyanobacterium Oscillatoria terebriformis in a sulfide-rich hot spring microbial mat. Appl Environ Microbiol 53:2142-2150

Roos JC, Vincent WF (1998) Temperature dependence of UV radiation effects on Antarctic cyanobacteria. J Phycol 34 $118-125$

Sokal RR, Rohlf FJ (1995) Biometry: the principles and practice of statistics in biological research. WH Freeman, New York

Vincent WF (1988) Microbial ecosystems of Antarctica. Cambridge University Press, Cambridge

Vincent WF, Quesada A (1994) Uitraviolet radiation effects on cyanobacteria: implications for Antarctic microbial ecosystems. In: Weiler CS, Penhale PA (eds) Ultraviolet radiation in Antarctica: measurements and biological effects. American Geophysical Union, Washington, DC, p 111-124

Vincent WF, Castenholz RW, Downes MT, Howard-Williams C (1993a) Antarctic cyanobacteria: light, nutrients, and photosynthesis in the microbial mat environment. J Phycol 29:745-755

Vincent WF, Downes MT, Castenholz RW, Howard-Williams $\mathrm{C}(1993 \mathrm{~b})$ Community structure and pigment organisation of cyanobacteria-dominated microbial mats in Antarctica. Eur J Phycol 28:213-221

Weiler CS, Penhale PA (eds) (1994) Ultraviolet radiation in Antarctica: measurements and biological effects. In: Antarctic research series. American Geophysical Union, Washington, DC

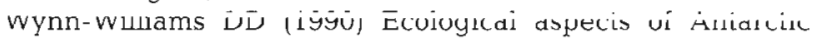
microbiology. Adv Microb Ecol 11:71-146

Wynn-Williams DD (1994) Potential effects of ultraviolet radiation on Antarctic primary terrestrial colonizers: cyanobacteria, algae, and cryptogams. In: Weiler CS, Penhale PA (eds) Ultraviolet radiation in Antarctica: measurements and biological effects. American Geophysical Union, Washington, DC, p 243-257

Submitted: December 20, 1998; Accepted: September 24, 1999 Proofs received from author(s): December 7, 1999 